\title{
GROWTH AND MINERAL NUTRITION OF RICE (Oryza sativa L.) GROWN ON TANNERY EFFLUENT POLLUTED SOIL AMENDED WITH COWDUNG AND LIME
}

\author{
Afrida, N., A. S. Chamon, M. K. Hossain, G. A. Shimi and M. N. Mondol \\ Department of Soil, Water and Environment, University of Dhaka, Dhaka-1000, Bangladesh
}

\begin{abstract}
Pot experiments were carried out with rice (Oryza sativa L.) to evaluate the plant response of different amendments to ameliorate heavy metal toxicity. Cowdung and lime were applied at the rate of $10 \mathrm{ton} / \mathrm{ha}$. Both cowdung and lime application led to an increase in growth of rice and significant reductions of $\mathrm{Zn}, \mathrm{Ni}, \mathrm{Cu}$ and $\mathrm{Cr}$ in plant. The length, fresh and dry weight and $\mathrm{N}, \mathrm{P}, \mathrm{K}, \mathrm{Na}, \mathrm{Ca}$ and $\mathrm{Mg}$ concentrations in rice plants were increased significantly. The concentrations of $\mathrm{Cu}, \mathrm{Zn}, \mathrm{Ni}, \mathrm{Pb}$ and $\mathrm{Cr}$ in rice grown on contaminated soils were significantly higher as compared to the control. Cowdung and lime significantly reduced $\mathrm{Cu}, \mathrm{Zn}, \mathrm{Ni}, \mathrm{Pb}$ and $\mathrm{Cr}$ concentrations in comparison to control. Chromium concentrations in lime treated plants were reduced by $57.89 \%$ in rice as compared to cowdung. Lime proved to be more efficient in reducing the concentration of metals in rice plants.
\end{abstract}

Key words: Cowdung, Chromium, Hazaribagh, Lime.

\section{INTRODUCTION}

Industrial effluents offer a wide scope of environmental problems and health hazards are becoming more complex and critical not only in developing countries like Bangladesh but also in developed countries. Soils are contaminated by a number of heavy metals that to a greater or lesser degree are toxic to humans and other animals or plants. Cadmium, chromium and mercury are extremely poisonous and lead, nickel, molybdenum and fluorine are moderate and boron, copper, manganese and zinc are relatively low in toxicity (Hellawell 1986).

Environmental pollution through industrialization is now a serious problem throughout the world. Soil is one of the major parts of the environment. People depend on soil for their basic needs. But soil and environment are under tremendous pressure due to industrial expansion and increased use of chemicals specially pesticides in agriculture during last few decades. Very few are aware of this globally important issue. The burning issue is how to feed an ever-growing population, which demands an urgent improvement of the gross national income through industrialization. Industrial pollutant refers to the presence of any elemental, ionic or molecular species in and around an industry or industrial areas at a concentration, which causes an adverse effect on life and environment. Soils are contaminated by a number of heavy metals that to a greater or lesser degree are toxic to humans and other animals or plants. The concentrations of individual metals in living tissue are ordinarily very low and must be maintained within narrow limits to permit the optimum biological performance of most organisms. Some heavy metals are essential in trace amounts, namely $\mathrm{Cu}, \mathrm{Fe}, \mathrm{Mn}$, Mo and $\mathrm{Zn}$ for plants and in addition $\mathrm{Cr}, \mathrm{Ni}$ and $\mathrm{Sn}$ for animals and $\mathrm{Cd}, \mathrm{Hg}$ and $\mathrm{Pb}$ are not essential for either plants or animals (Greenland and Hayes 1981).

Heavy metals cause inhibition of plant growth by affecting different plant processes, i.e. photosynthesis (Becerill et al. 1988), respiration (Keek 1978), carbohydrate metabolism and water relations (Becerill et al. 1988). The uptake of heavy metals by plants from contaminated soils is of great interest because an excess of dietary intake of some of these heavy metals might be deleterious to the health of the consumers. Food chain contamination is one of the important pathways for the entry of 
these toxic pollutants into the human body (Ma et al. 2006). Therefore, the present study was undertaken to prevent heavy metal accumulation in rice plant (Bridhan-58) grown in Hazaribagh tannery area soil.

\section{MATERIAL AND METHODS}

Soil sample was collected from Hazaribagh tannery area and Rice (Oryza sativa L.) (BR-58) was selected as test crop. The soil series around Hazaribagh belonging to Khaler Char remains seasonally flooded, up to 120-150 cm deep for more than 6 months and they are poorly to very poorly drained soils, developed in mainly medium textured Brahmaputra alluvium in permanently wet channels or depression on the old and young Brahmaputra, Meghna and Jamuna floodplains. The area inside the embankment is just organic wastes, on Jamuna alluvium, permanently wet by the effluents of the tannery factories.

The normal soil sample was collected from Shudkhira village in Jamirta union of Singair upazilla at Manikganj District. Soil samples (0-15 cm depth) were collected from both Hazaribagh (contaminated soil) and Singair (uncontaminated soil). The soil samples collected were air-dried, ground and screened to pass through $5 \mathrm{~mm}$ sieve for pot experiment and $2.0 \mathrm{~mm}$ and $0.5 \mathrm{~mm}$ sieve for physical and chemical analyses.

There were 4 treatments $\left(\mathrm{T}_{1}, \mathrm{~T}_{2}, \mathrm{~T}_{3}\right.$ and $\left.\mathrm{T}_{4}\right)$ and three replications in the experiment is presented in Table 1. Plastic pots were filled with $4 \mathrm{~kg}$ soil and basal dose of fertilizers as urea, TSP and muriate of potash were added at medium rate for rice (BARC 2012). Three plants of two weeks old were allowed to grow in each pot. The pots were arranged in a completely randomized design. The plants were irrigated with distilled water whenever required. The crops were harvested after two months of transplantation.

Soil samples were digested with $\mathrm{HCl}$ plus $\mathrm{HNO}_{3}$ (3:1) mixture (Blum 1996) under closed system. $0.5 \mathrm{~g}$ of finely ground plant sample was weighed and digested with $10 \mathrm{ml}$ conc. $\mathrm{HNO}_{3}$ and $2 \mathrm{ml}$ conc. $\mathrm{HClO}_{4}$. Elements in the extracts $(50 \mathrm{ml})$ were measured by atomic absorption spectrophotometer (AAS) (Varian, AA-240). The data were statistically analyzed by Duncan's Multiple Range Test (DMRT) in IBM SPSS statistics version 20 (Gomez and Gomez 1984).

Table 1: Description of the treatments.

\begin{tabular}{ll}
\hline Denotation & Treatments \\
\hline $\mathrm{T}_{1}($ Control) & Normal/uncontaminated soil \\
$\mathrm{T}_{2}$ & Hazaribagh soil (Tannery polluted soil) \\
$\mathrm{T}_{3}$ & Hazaribagh soil plus Cowdung \\
$\mathrm{T}_{4}$ & Hazaribagh soil plus Lime \\
\hline Pots: $4 \mathrm{~kg}$ soil/pot, 3 replications, Test Crop: Rice (Bridhan-58), 3 plans/pot, Cowdung/lime: 10 ton/ha
\end{tabular}

\section{RESULTS AND DISCUSSION}

\section{Metal concentrations of Hazaribagh Tannery Industrial area soils}

Physicochemical properties of the soils of Hazaribagh tannery area are presented in Table 2. The moisture content of the soil at sampling time was $36.64 \%$. The mineralization of tannery wastes contributed to this high nitrogen concentration.

The soil from Hazaribagh tannery area shows high concentrations of heavy metal and an exception for cadmium, rest of the metals are present at a level higher than the MAC (Maximum allowable concentration) for soil (Kloke 1980). The concentration of chromium shows the maximum value among other metals (130630.8 mg kg-1). Ullah et al. (1999) reported $25014 \mathrm{mg} \mathrm{kg}^{-1}$ chromium concentration at Hazaribagh area. Similar findings were also reported by many authors. Elahi et al. (2010) reported $59333.33 \mathrm{mg} \mathrm{kg}^{-1}$ of $\mathrm{Cr}$ concentration in soil. This high concentration of chromium may have occurred due to the use of chromium sulphate $\left(\left[\mathrm{Cr}\left(\mathrm{H}_{2} \mathrm{O}\right) 6\right] 2(\mathrm{SO} 4) 3\right)$, regarded as one of the most 
efficient and effective tanning agent, during liming, pickling and curing stage. Along with this high amount of chromium phosphate is also used at liming process due to its efficiency in removing natural grease, fats, hairs, nails and other keratinous matters.

Table 2. Physicochemical properties of Hazaribagh soil.

\begin{tabular}{l|c|cc}
\hline Properties & Value & HNO $_{\mathbf{3}}$-HCl extractable metals in $\mathbf{~ m g ~}^{\mathbf{- 1}}$ \\
\hline Texture & Sandy loam & $\mathrm{Cr}$ & 130630.8 \\
$\mathrm{pH}$ & 6.94 & $\mathrm{Cu}$ & 143.13 \\
Organic Matter (\%) & 3.11 & $\mathrm{~Pb}$ & 223.33 \\
& & $\mathrm{Cd}$ & $\mathrm{BDL}$ \\
Total N (\%) & 3.62 & $\mathrm{Zn}$ & 581.96 \\
Total P (\%) & 0.36 & $\mathrm{Ni}$ & 216.66 \\
Total K (\%) & 0.09 & & \\
Total Na (\%) & 0.13 & & \\
Total Ca (\%) & 0.05 & & \\
Total Mg (\%) & 0.01 & & \\
\hline
\end{tabular}

BDL= Below detection limit

The concentrations of copper, lead, zinc and nickel is $143.13,223.33,581.96$ and $216.66 \mathrm{mg} \mathrm{kg}^{-1}$ respectively at sampling time which have crossed the MAC for soil (Kloke 1980). The cadmium concentrations, however, was below detection level. Such high concentrations of heavy metals were previously reported by many authors (Nuruzzaman et al. 1998, Ullah et al. 1999, Elahi et al. 2010).

\section{Growth and yield of rice (Oryza sativa L.)}

The length of shoot and root of rice (Bridhan-58) and its fresh and dry weight is affected by different treatments as shown in Table 3. The length of shoot and root ranged from 31.16 to 55.50 and 7.90 to $12.83 \mathrm{~cm}$, respectively. The maximum and the minimum length of both shoot and root were obtained in Hazaribagh soil treated with lime $\left(\mathrm{T}_{4}\right)$ and Hazaribagh soil $\left(\mathrm{T}_{2}\right)$ respectively. In case of root the length increased by $5.28 \%$ in $\mathrm{T}_{3}$ compared with the control $\left(\mathrm{T}_{1}\right)$ and by $21.03 \%$ in $\mathrm{T}_{4}$ compared with $\mathrm{T}_{1}$. The length of root increased by $14.96 \%$ in $\mathrm{T}_{4}$ compared to $\mathrm{T}_{3}$. The result indicated that the shoot and root length increased significantly due to application of cowdung and lime (Table 3).

Table 3. Effect of cowdung and lime on growth parameters of Rice (Bridhan-58).

\begin{tabular}{l|cc|cc|cc}
\hline \multirow{2}{*}{ Treatments } & \multicolumn{2}{|c|}{ Length $(\mathbf{c m})$} & \multicolumn{2}{c|}{ Fresh weight (g/plant) } & \multicolumn{2}{c}{ Dry weight (g/plant) } \\
\cline { 2 - 7 } & Shoot & Root & Shoot & Root & Shoot & Root \\
\hline $\mathrm{T}_{1}($ Control) & $42.00 \mathrm{~b}$ & $10.60 \mathrm{~b}$ & $2.64 \mathrm{~b}$ & $1.24 \mathrm{~b}$ & $2.28 \mathrm{~b}$ & $0.87 \mathrm{~b}$ \\
$\mathrm{~T}_{2}$ & $31.16 \mathrm{a}$ & $7.90 \mathrm{a}$ & $1.69 \mathrm{a}$ & $0.35 \mathrm{a}$ & $1.33 \mathrm{a}$ & $0.23 \mathrm{a}$ \\
$\mathrm{T}_{3}$ & $51.00 \mathrm{c}$ & $11.16 \mathrm{~b}$ & $3.31 \mathrm{bc}$ & $1.38 \mathrm{~b}$ & $2.81 \mathrm{bc}$ & $1.08 \mathrm{~b}$ \\
$\mathrm{~T}_{4}$ & $55.50 \mathrm{~d}$ & $12.83 \mathrm{~b}$ & $3.48 \mathrm{c}$ & $1.40 \mathrm{~b}$ & $3.17 \mathrm{c}$ & $1.14 \mathrm{~b}$ \\
\hline \multicolumn{3}{r}{} \\
\multicolumn{3}{r}{ Means followed by the same letter(s) in a column do not differ significantly from each other at 5\% level by DMRT }
\end{tabular}

The maximum fresh weight of shoot/plant and root/pot were $3.48 \mathrm{~g}$ and $1.40 \mathrm{~g}$ obtained in the lime treatment $\left(\mathrm{T}_{4}\right)$ (Table 3 ). The lowest value was $1.69 \mathrm{~g}$ for shoot and $0.35 \mathrm{~g}$ for root in the treatment $\mathrm{T}_{2}$ (Hazaribagh soil). The decrease in the fresh weight of shoot and root followed the sequence of $\mathrm{T}_{4}>\mathrm{T}_{3}>\mathrm{T}_{1}>\mathrm{T}_{2}$. Application of cowdung and lime significantly increased the fresh weight of shoot. The fresh weight of shoot increased by 25.4 and $31.8 \%$ in cowdung $\left(\mathrm{T}_{3}\right)$ and lime $\left(\mathrm{T}_{4}\right)$ treated pots compared to the control $\left(\mathrm{T}_{1}\right)$. Again the fresh weight of root increased by 11.3 and $12.9 \%$ in cowdung $\left(\mathrm{T}_{3}\right)$ and 
lime $\left(\mathrm{T}_{4}\right)$ treated pots compared to the control $\left(\mathrm{T}_{1}\right)$. Fresh weigh of root increased by $1.45 \%$ in $\mathrm{T}_{4}$ compared to $\mathrm{T}_{3}$.

The maximum dry weight of shoot/plant and root/plant were $3.17 \mathrm{~g}$ and $1.14 \mathrm{~g}$ obtained in the treatment $\mathrm{T}_{4}$ (Hazaribagh soil plus lime). The lowest value was $1.33 \mathrm{~g}$ and $0.23 \mathrm{~g}$ in the treatment $\mathrm{T}_{2}$ (Hazaribagh soil) for shoot and root, respectively. The decrease in the fresh weight of shoot and root followed the sequence of $\mathrm{T}_{4}>\mathrm{T}_{3}>\mathrm{T}_{1}>\mathrm{T}_{2}$. Application of cowdung and lime significantly increased the dry weight of shoot and root. The changes in dry weight of root do not differ significantly among $T_{1}, T_{3}$ and $\mathrm{T}_{4}$. The changes in the growth factors of rice were previously demonstrated by other authors as well as the beneficial impact of lime and organic amendments. Gerzabeck and Ullah (1990) observed that the reduction in shoot and root length by the toxic impacts of heavy metals. The positive influence of organic substances on plant growth is due to indirect effects of humic substances acting as suppliers and regulators of plant nutrients and due to direct effects of humic substances e.g. as respiratory catalysts (Schnitzer and Khan 1978, Vaughan and Malcolm 1985).

\section{Mineral nutrition of rice}

Application of treatments (lime and cowdung) significantly enhanced the macronutrient concentration in shoots and roots of rice (Bridhan-58) (Table 4). Nitrogen concentration ranged from 2.63 to $4.10 \%$ in shoot and 0.79 to $3.30 \%$ in root. The nitrogen concentration in shoot increased by $12.20 \%$ in $\mathrm{T}_{3}$ compared to $\mathrm{T}_{1}$ and by $8.75 \%$ in $\mathrm{T}_{4}$ compared to $\mathrm{T} 3$ (Table 4). The changes in nitrogen concentration in root are not significant between $T_{1}$ and $T_{2}$ as well as between $T_{3}$ and $T_{4}$. However $T_{1}$ and $\mathrm{T}_{2}$ were significantly different from $\mathrm{T}_{3}$ and $\mathrm{T}_{4}$ respectively. The nitrogen concentration was decreased by $20.25 \%$ in $\mathrm{T}_{2}$ compared to $\mathrm{T}_{1}$ and increased by $6.79 \%$ in $\mathrm{T}_{4}$ compared to $\mathrm{T}_{3}$. From the results, it was evident that the higher the concentration of heavy metal the lower was the concentration of nitrogen in root and shoot of rice plant. Chamon et al. (2005) reported that application of cowdung and water hyacinth in the polluted soil enhanced the nitrogen concentration in rice. Strand et al. (1990) and Lee et al. (1991) reported an antagonistic effect on nitrogen uptake by rice plants due to application of heavy metals. In most cases, heavy metals block the entry of $\mathrm{N}$ in the root system (Sharma et al. 2006).

Phosphorus concentration ranged from 0.22 to $0.26 \%$ in shoot and 0.10 to $0.22 \%$ in root. The highest value of $0.26 \%$ in shoot and of $0.22 \%$ in root was found for $\mathrm{T}_{4}$ (Hazaribagh soil plus lime) and the lowest value of $0.22 \%$ in shoot and $0.10 \%$ in root was found for $\mathrm{T}_{1}$ (Control). The phosphorus concentration in shoot increased by $13.63 \%$ in $\mathrm{T}_{2}$ compared to $\mathrm{T}_{1}$ and by $4 \%$ in $\mathrm{T}_{3}$ compared to $\mathrm{T}_{2}$ and decreased by $3.84 \%$ in $\mathrm{T}_{4}$ compared to $\mathrm{T}_{3}$ (Table 3). Jasmin et al. (2020) stated that application of cowdung along with lead significantly increased phosphorus concentration in grain and straw of rice as compared to lead contaminated soil. Chamon et al. (2005) reported that application of cowdung and water hyacinth in the polluted soil enhanced the phosphorus contents in rice.

Potassium concentration ranged from 0.96 to $1.66 \%$ in shoot and 0.58 to $1.15 \%$ in root. The highest concentration of potassium was found in the shoot and root of rice at lime $\left(\mathrm{T}_{4}\right)$ and cowdung $\left(\mathrm{T}_{3}\right)$ treated pots, respectively. The lowest concentration was found in $\mathrm{T}_{1}$ (Control) (Table 4).

Potassium concentration in shoot increased by $14.23 \%$ in Hazaribagh soil $\left(\mathrm{T}_{2}\right)$ compared to the control $\left(\mathrm{T}_{1}\right)$ and by $8.21 \%$ in cowdung treated pots $\left(\mathrm{T}_{3}\right)$ compared to Hazaribagh soil $\left(\mathrm{T}_{2}\right)$ and by $40.45 \%$ in lime treated pots $\left(\mathrm{T}_{4}\right)$ compared to cowdung treated pots $\left(\mathrm{T}_{3}\right)$. In root of rice it increased by $38.46 \%$ in cowdung treated pots $\left(\mathrm{T}_{3}\right)$ compared to Hazaribagh soil $\left(\mathrm{T}_{2}\right)$ and decreased by $20.14 \%$ in lime treated pots $\left(\mathrm{T}_{4}\right)$ compared to cowdung treated pots $\left(\mathrm{T}_{3}\right)$. Calcium concentration ranged from 0.18 to $0.52 \%$ in shoot and 0.34 to $0.48 \%$ in root. Magnesium concentration ranged from 0.02 to $0.15 \%$ in shoot and 0.03 to $0.12 \%$ in root. The highest concentration for both calcium and magnesium is 
found at lime amended treatment $\left(\mathrm{T}_{4}\right)$ for both shoot and root and the lowest concentrations were found in the control $\left(\mathrm{T}_{1}\right)$ for both shoot and root. The accumulation of calcium was much higher in root than in shoot at the control $\left(\mathrm{T}_{1}\right)$ and the pots with Hazaribagh soil $\left(\mathrm{T}_{2}\right)$. The reduced calcium concentration in Hazaribagh soil $\left(\mathrm{T}_{2}\right)$ might be due to the antagonistic effect of heavy metals with calcium. The highest magnesium concentration was found at lime amended treatment $\left(\mathrm{T}_{4}\right)$ for both shoot and root and the lowest concentrations were found in the control $\left(\mathrm{T}_{1}\right)$ for both shoot and root. From the results it is evident that the magnesium concentration increased when lime and cowdung was added as treatments. Phosphorus, calcium, magnesium and potassium uptake by soybean plant was enhanced by lime and cowdung application (Martini and Mutters 1985).

Table 4. Effect of cowdung and lime on the concentration of $\mathrm{N}, \mathrm{P}, \mathrm{K}, \mathrm{Ca}$ and $\mathrm{Mg}$ in shoots and roots of rice.

\begin{tabular}{l|cc|cc|cc|cc|cc}
\hline \multirow{2}{*}{ Treatments } & \multicolumn{2}{|c|}{ \% Nitrogen } & \multicolumn{2}{|c|}{ \%Phosphorus } & \multicolumn{2}{c|}{ \%Potassium } & \multicolumn{2}{c|}{ \%Calcium } & \multicolumn{2}{c}{ \%agnesium } \\
\cline { 2 - 10 } & Shoot & Root & Shoot & Root & Shoot & Root & Shoot & Root & Shoot & Root \\
\hline $\mathrm{T}_{1}($ Control $)$ & $3.36 \mathrm{~b}$ & $0.79 \mathrm{a}$ & $0.22 \mathrm{a}$ & $0.10 \mathrm{a}$ & $0.96 \mathrm{~b}$ & $0.58 \mathrm{a}$ & $0.18 \mathrm{a}$ & $0.34 \mathrm{a}$ & $0.02 \mathrm{a}$ & $0.03 \mathrm{a}$ \\
$\mathrm{T}_{2}$ & $2.63 \mathrm{a}$ & $0.63 \mathrm{a}$ & $0.25 \mathrm{ab}$ & $0.14 \mathrm{~b}$ & $1.09 \mathrm{a}$ & $1.04 \mathrm{~b}$ & $0.19 \mathrm{a}$ & $0.39 \mathrm{a}$ & $0.02 \mathrm{a}$ & $0.04 \mathrm{a}$ \\
$\mathrm{T}_{3}$ & $3.77 \mathrm{bc}$ & $3.09 \mathrm{~b}$ & $0.26 \mathrm{~b}$ & $0.18 \mathrm{c}$ & $1.18 \mathrm{a}$ & $1.44 \mathrm{~b}$ & $0.49 \mathrm{~b}$ & $0.37 \mathrm{a}$ & $0.11 \mathrm{~b}$ & $0.08 \mathrm{~b}$ \\
$\mathrm{~T}_{4}$ & $4.10 \mathrm{c}$ & $3.30 \mathrm{~b}$ & $0.25 \mathrm{ab}$ & $0.22 \mathrm{~d}$ & $1.66 \mathrm{a}$ & $1.15 \mathrm{~b}$ & $0.52 \mathrm{~b}$ & $0.48 \mathrm{~b}$ & $0.15 \mathrm{c}$ & $0.12 \mathrm{c}$ \\
\hline
\end{tabular}

Means followed by the same letter(s) in a column do not differ significantly from each other at $5 \%$ level by DMRT

\section{Heavy metal concentration in rice}

Heavy metal concentration ameliorated by lime and cowdung of rice (Bridhan-58) is presented in Table 5. Chromium concentration ranged from 4.66 to $262.73 \mathrm{mg} \mathrm{kg}^{-1}$ in shoot and 17.26 to $914.53 \mathrm{mg}$ $\mathrm{kg}^{-1}$ in root. The highest concentration of chromium was found in the shoot and root of rice at $\mathrm{T}_{2}$ and $\mathrm{T}_{4}$, respectively. The lowest concentration was found in $\mathrm{T}_{1}$ (control). In case of root there was no significant difference between $T_{2}$ and $T_{3}$ but these two treatments were significantly different from that of $\mathrm{T}_{1}$ (control) and lime treatment $\left(\mathrm{T}_{4}\right)$.

Copper concentration ranged from 6.20 to $11.80 \mathrm{mg} \mathrm{kg}^{-1}$ in shoot and 21.80 to $44.56 \mathrm{mg} \mathrm{kg}^{-1}$ in root. The highest concentration of copper was found in the shoot and root of rice at $\mathrm{T}_{2}$ (Hazaribagh soil). The lowest concentration was found in shoot at $\mathrm{T}_{1}$ (control) and in root at $\mathrm{T}_{4}$ (lime treatment). The zinc concentration ranged from 61.74 to $181 \mathrm{mg} \mathrm{kg}^{-1}$ in shoot and 196.47 to $903.20 \mathrm{mg} \mathrm{kg}^{-1}$ in root.

Table 5. Effects of cowdung and lime on micronutrient concentration $\left(\mathrm{mg} \mathrm{kg}^{-1}\right)$ of rice.

\begin{tabular}{l|cc|cc|cc|cc|cc}
\hline \multirow{2}{*}{ Treatments } & \multicolumn{2}{|c|}{ Copper } & \multicolumn{2}{c|}{ Chromium } & \multicolumn{2}{c|}{ Zinc } & \multicolumn{2}{c|}{ Nickel } & \multicolumn{2}{c}{ Lead } \\
\cline { 2 - 10 } & Shoot & Root & Shoot & Root & Shoot & Root & Shoot & Root & Shoot & Root \\
\hline $\mathrm{T}_{1}$ (Control) & $6.2 \mathrm{a}$ & $32.8 \mathrm{~b}$ & $4.7 \mathrm{a}$ & $17.3 \mathrm{a}$ & $61.7 \mathrm{a}$ & $196.5 \mathrm{a}$ & $5.2 \mathrm{a}$ & $32.7 \mathrm{~b}$ & $35.3 \mathrm{a}$ & $53.1 \mathrm{a}$ \\
$\mathrm{T}_{2}$ & $11.8 \mathrm{c}$ & $44.6 \mathrm{c}$ & $262.7 \mathrm{~b}$ & $508 \mathrm{~b}$ & $122.5 \mathrm{~b}$ & $279.1 \mathrm{a}$ & $11.8 \mathrm{~b}$ & $27.9 \mathrm{~b}$ & $44.7 \mathrm{a}$ & $102.3 \mathrm{~b}$ \\
$\mathrm{~T}_{3}$ & $10.5 \mathrm{c}$ & $24.6 \mathrm{ab}$ & $56.8 \mathrm{~b}$ & $443.7 \mathrm{~b}$ & $181 \mathrm{c}$ & $363.3 \mathrm{a}$ & $6.5 \mathrm{a}$ & $13.5 \mathrm{a}$ & $40 \mathrm{a}$ & $72 \mathrm{a}$ \\
$\mathrm{T}_{4}$ & $8.3 \mathrm{~b}$ & $21.8 \mathrm{a}$ & $23.9 \mathrm{ab}$ & $914.5 \mathrm{c}$ & $101.3 \mathrm{ab}$ & $903.2 \mathrm{a}$ & $6.3 \mathrm{a}$ & $13.3 \mathrm{a}$ & $43.7 \mathrm{a}$ & $51 \mathrm{a}$ \\
\hline
\end{tabular}

Means followed by the same letter(s) in a column do not differ significantly from each other at $5 \%$ level by DMRT

The highest concentration of zinc was found in the shoot and root of rice at cowdung $\left(\mathrm{T}_{3}\right)$ and lime $\left(\mathrm{T}_{4}\right)$ amended soil, respectively. The lowest concentration was found in $\mathrm{T}_{1}$ (control). The nickel concentration ranged from 5.20 to $11.80 \mathrm{mg} \mathrm{kg}^{-1}$ in shoot and 13.33 to $32.77 \mathrm{mg} \mathrm{kg}^{-1}$ in root. The highest concentration of nickel was found in the shoot and root of rice at $\mathrm{T}_{2}$ (Hazaribagh soil). The lowest concentration was found in shoot at $\mathrm{T}_{1}$ (control) and in root at $\mathrm{T} 4$ (lime treatment). Lead concentration ranged from 35.33 to $44.67 \mathrm{mg} \mathrm{kg}^{-1}$ in shoot and 51 to $102.33 \mathrm{mg} \mathrm{kg}^{-1}$ in root. In case of shoot there was no significant difference among treatments. The highest concentration of lead was 
found in the shoot and root of rice at $\mathrm{T}_{2}$ (Hazaribagh soil). The lowest concentration was found at $\mathrm{T}_{1}$ (control) for shoot and at $\mathrm{T}_{4}$ (lime treated pots) for root (Table 5).

Application of cowdung and lime significantly affected the chromium concentration in rice. In case of shoot lime was more efficient in reducing chromium concentration in rice. Similar results were found by Chamon et al. (2005). Palazzo and Reynolds (1991) found that total and extractable copper, zinc, chromium, nickel, lead and cadmium in soil decreased significantly with time due to lime application. The plant tissue concentration of metals also decreased due to liming with time. Chromium in the plant grown on same soil at Hazaribagh tannery area was much above the permissible limit $\left(\mathrm{mg} \mathrm{kg}^{-1}\right)$ (Kloke 1980).

Application of lime and cowdung reduced the metal toxicity of soil. The lime and cowdung reduced the mobility of heavy metals thus reducing its uptake to rice plant (Chamon et al. 2005).

\section{ACKNOWLEDGEMENTS}

The authors gratefully acknowledge the Department of Soil, Water and Environment, University of Dhaka for giving all the facilities needed to carry out the present research work.

\section{REFERENCES}

BARC (Bangladesh Agricultural Research Council). 2012. Fertilizer Recommendation Guide. Soil publication no. 32. pp. 108-109.

Becerril, J. M., A. Munoz-Rueda, C. Gonzalez-Murua and M. R. De Felipe. 1989. Changes induced by cadmium and lead in gas exchange and water. Biochem. 27: 913-918.

Blum, W. E. H. 1996. Soil protection concept of the Council of Europe. In: A. J. B. Zehnder (ed). Soil and Ground Water pollution. Kluwer Academic Publisher. Dordrecht., pp. 72-73.

Chamon, A. S., M. H. Gerzabek, M. N. Mondol, S. M. Ullah, M. Rahman and W. E. H. Blum. 2005. Influence of soil amendments on heavy metal accumulation in crops on polluted soils of Bangladesh. Comm. Soil Sci. Plant Anal. 36: 907-924.

Elahi, S. F., A. S. Chamon, B. Faiz, M. N. Mondol and M. H. Rahaman. 2010. Specification of heavy metals in soils, plants and water in Bangladesh. Bangladesh. J. Agric. Environ. 5(2): 79-97.

Gerzabek, M. H. and S. M. Ullah. 1990. Influence of fulvic and humic acids on Cd- and Ni- toxicity to Zea mays (L.). Bodenkultur. 41: 115-124.

Gomez, A. K. and A. A. Gomez. 1984. Statistical Procedures for agricultural research. 2nd ed. John Wiley and Sons. New York, USA.

Greenland, D. J. and M. H. B. Hayes. 1981. The Chemistry of Soil Processes. John Wiley and Sons Ltd.

Hellawell, J. M. 1986. Biological Indicators of Freshwater Pollution and Environmental Management. Elsvier Applied Science Publisher. London, UK.

Jasmin, P., W. Z. Prian, M. N. Mondol, S. M. Ullah and A. S. Chamon. 2020. Effects of lead (Pb) on growth, yield and mineral nutrition of Kalmi (Oryza sativa L.) and its remediation. J. Biodiverse. Conserve. Bioresour. Manag. 5(2): 83-92.

Keek, R. W. 1978. Cd alteration of root physiology and potassium ion fluxes. Plant Physiol. 62: 94-96.

Kloke, A. 1980. Orientierungslaten fur tolerierbare Gesamtgehalte einiger Elemente in Kulturböden. Mitteilungen der VDLUFA Heft. 1-3: 9-11. 
Lee, S. J. and J. E. Kim 1991. Pollution of $\mathrm{Pb}$ in paddy field, soil and rice plants at road side areas. Korean Environ. Agric. 10: 138-148.

Ma, H. W., M. L. Hung and P. C. Chen. 2006. A systemic health risk assessment for the chromium cycle in Taiwan. Environ. Intern. 10: 1016-1023.

Martini, J. A. and R. G. Mutters. 1985. Effect of lime rates on nutrient availability, mobility, and uptake during the soyabean-growing season: 2. Calcium, magnesium, potassium, iron, copper, and zinc. Soil Sci. 139(4): 333-343.

Nuruzzaman, M., M. H. Gerzabek, A. Islam, M. H. Rashid and S. M. Ullah. 1998. Contamination of soil environment by the tannery industries. Bangladesh J. Soil. Sci. 25(1): 1-10.

Palazzo, A. J. and C. M. Reynolds. 1991. Long term changes in soil and plant metal concentration in acidic dredge disposal site receiving sewage sludge. Water, Air, and Soil Poll. 57-58: 839-848.

Schnitzer, M. and S. U. Khan. 1978. Soil Organic Matter. Elsevier Scientific Publishing company, Amsterdam, Oxford, New York.

Sharma, R. K., M. Agrawal and F. Marshall. 2006. Heavy metal contamination in vegetables grown in wastewater irrigated areas of Varanasi, India. Bull. Environ. Contam. Toxicol. 77: 312-318.

Strand, V., B. N. Zolotareva and A. S. Lisovskij. 1990. Effect of Pb, Cd and Cu content in the soil on their accumulation in and yields of crops. Rostlinnavyroba. 4: 411- 417.

Ullah, S. M., M. H. Gerzabek, M. N. Mondol, M. M. Rashid and M. Islam. 1999. Heavy metal pollution of soils and water and their transfer into plants in Bangladesh. In Proc. of extended Abstracts. 5th International Conference on the Biogeochemistry of Trace Elements (W. W. Wenzel, D. C. Adriano, B. Alloway, H. E. Doner, C. Keller, N. W. Lepp, M. Mench, R. Naidu and G. M. Pierzynski. (eds). Vienna, Austria. I: 260-61UNB, November, 2003: 96-108.

Vaughan, D. and R. E. Malcolm. 1985. Soil Organic Matter and Biological Activity. Martinus Nijhoff/Dr. W. Junk Publishers, Dordrecht, Boston, Lancaster. 
